Ethiopian Journal of Environmental Studies \& Management 9(Suppl. 2): 1009 - 1021, 2016. ISSN:1998-0507 doi: http://dx.doi.org/10.4314/ejesm.v9i2.7S

Submitted: August 22, 2016 Accepted: December 15, 2016

\title{
INFLUENCE OF SOME ENVIRONMENTAL FACTORS ON MAIZE PRODUCTIVITY IN OSUN STATE, NIGERIA
}

\author{
*LAMIDI, WASIU AGUNBIADE. AND AFOLABI, MICHAEL SEGUN \\ Department of Agronomy, College of Agriculture, Ejigbo, Osun State University, \\ Osogbo, Nigeria
}

\begin{abstract}
Temperature, humidity and direction of the prevailing wind are parts of significant environmental factors, which have greater impact on crop productivity, especially with the recent global climate change. These were researched into on maize seeds planted at three different furrow orientations on the field; Or. $90^{\circ}$, Or. $60^{\circ}$ and Or. $30^{\circ}$ to direction of the prevailing wind on the same plot of land at three replicates $A, B$ and $C$ each. Temperature and humidity were measured at $8.00 \mathrm{hr}, 10.00 \mathrm{hr}$ for morning; $14.00 \mathrm{~h}$ and $16.00 \mathrm{~h}$ for afternoon each day. Temperature-Humidity Index-THI was calculated using THI equation. Leaf development was measured in terms of broadness, stem girth, length and number of leaves. Harvest Index, HI and Leaf Area Index, LAI were also calculated. The result shows that at significant level $(p<0.05)$, effect of Or. was observed on THI values in the afternoon period, but in the morning, significant ( $p>$ 0.05) effect of orientation on THI was not observed. The Or. $90^{\circ}$ had highest HI of maize and better growth. The LAI values show that Or. $90^{\circ}$ had higher LAI (0.775), than that of Or. $60^{\circ}$ of value (0.770), between 40th and 70th days. It was found out that orientation of furrow of maize crops to direction of the prevailing is a function of the environmental parameters such as temperature, humidity, and the closer the orientation of furrow slice for crop leaves is towards the $90^{\circ}$ wind direction, the better its growth and yield.
\end{abstract}

Key Words: Crop productivity, Leaf Area Index, Temperature-Humidity Index, orientation, Osun State

\section{Introduction}

The prevailing global climate change is making a great impact on the world climatic condition, making it more difficult to predict weather condition for accurate and successful annual farming (Ibrahim et al., 2013; Carns et al., 2013; Olaoye and Rotimi, 2010). Though crops are planted in both rainy and dry seasons, each crop has its own set of environmental conditions under which it grows most effectively (Watson, 2015; Plessis, 2003; Ogunjimi, et al., 2014;
Lamidi, 2013). Soil and air temperatures have effects on many aspects of crop growth and development, leaf growth and expansion and are all correlated (QiJin and GuangSheng, 2012; Lamidi, 2009). For instance, the rate of appearance of leaves in sugar beet increases with temperature over the range $5-15^{\circ} \mathrm{C}$ before reaching a plateau and then declines above $30^{\circ} \mathrm{C}$ ( Fageria et al., 2009). In maize and soybeans the rate of leaves appearance is also dependent on temperature and increases

*Corresponding Author: Lamidi, W.A.

Email: wasiu.agunbiade@uniosun.edu.ng 
over the range $15-30^{\circ} \mathrm{C}-$ thus high temperature is needed, a reason while they are not grown widely in cool temperature regions of the world (Fageria, 2009).

Crop and some Environmental factors

Information on soil temperature is needed for the crop survival (IFPRI, 2004). For instance, wheat, barley and brassicas seeds need $6-10^{\circ} \mathrm{C}$ soil temperature to germinate while maize needs minimum $10^{\circ 0} \mathrm{C}$ (Fageria, 2009). Temperature also affects root development of crops (how this happens is not yet clearly defined); in maize for example the rate of elongation of the seminal roots increases between $10^{\circ} \mathrm{C}$ and $30^{\circ} \mathrm{C}$ after which it declines (Fageria, 2009). These effects influence the rate of development of the root system and its ability to absorb water and nutrients from soil for growth. Also initiation of flowering in many crop plants is stimulated by exposure to low temperature (Ibrahim et al., 2013; Carns et al., 2013; Ammani et al., 2012; Qi Jin and GuangSheng, 2012). Maize crops planted by machine are precisely placed in hole such that their stalks' position may be toward nearly the same direction along the furrow row especially when the seed hopper is well calibrated, their stands are set precisely when 95-99\% germination is obtained.

\section{THI Equation}

The dry-bulb temperature and humidity through TemperatureHumidity Index (THI) are two environmental parameters developed by Thom in 1958 and adopted by U.S. Weather Bureau in 1959 as a comfort equation for living things, normally expressed as

$$
\mathrm{THI}=\mathrm{t}_{\mathrm{ab}}+0.36 \mathrm{t}_{\mathrm{db}}+41.5 \ldots \text { (1) }
$$

where $t_{a b}$ and $t_{d b}$ are the dry bulb and dew point temperatures in ${ }^{\circ 0} \mathrm{C}$, this equation was further developed and improved upon by Marai et al. (2001) to become

$$
\mathrm{THI}=\mathrm{db}^{\mathrm{o}} \mathrm{C}-\{[0.31-0.31
$$

$\left.\left.\left[\frac{R H}{100}\right]\right]\left(\mathrm{db}^{\circ} \mathrm{C}-14\right)\right\} \quad \ldots$

where $\mathrm{db}^{\circ} \mathrm{C}=$ dry bulb temperature in Celcius and $\mathrm{RH}=$ relative humidity in $\%$

THI relates the combined effects of dry-bulb temperatures and humidity to any living organism's comfort and performance. Although it is usually used for animals, it could by extension apply to crop plants. The objective of the research was to investigate the effects of the variations in temperature, humidity and prevailing wind direction on maize crop productivity in terms of its leaves' broadness, length, number, stem girth and grain yield.

\section{Materials and Method}

Three acres of maize were planted on a good loam soil at a farm in Osogbo, Osun State, a city in the south western part of Nigeria (longitude $4.56^{\circ} \mathrm{E}$ and latitude $7.75^{\circ} \mathrm{N}$ ) for the study. Each acre of dimension $80 \mathrm{~m} \times$ $50 \mathrm{~m}$ was divided into three sections $\mathrm{A}$, $\mathrm{B}$ and $\mathrm{C}$ to make nine plots. Each of the three plots in each acre was of dimension $24 \mathrm{~m} \times 50 \mathrm{~m}$, planted with maize in three different furrow slices with space $2 \mathrm{~m} \times 50 \mathrm{~m}$ in between them. The three plots in each acre were planted at Or. $90^{\circ}$, Or. $60^{\circ}$ and Or. $30^{\circ}$ to the direction of the prevailing wind. The whole arrangement was made into three replicates, that is A1 at Or. $90^{\circ}$, $\mathrm{A} 2$ at Or. $60^{\circ}, \mathrm{A} 3$ at Or. $30^{\circ}$ and the same for $\mathrm{B}$ and $\mathrm{C}$ replicates. It was a 3 $\times 3$ factorial design where the direction of the prevailing wind was found through the use of wind vane. 


\section{Crop Arrangement in the Field}

During the planting, the seeds were carefully placed in their holes almost precisely, since the plots and the spots of planting were measured before. Each of the 9 plots was on the field with $6-$ $8 \%$ slope and this is within the permissible range of land adequate for farming (Schwab et al., 1981). The whole area is vast with no canopy of any form, thus it is $100 \%$ exposed to the solar radiation and precipitation. Although the plots were not mechanically cleared, plough or planted with seed, all were manually done, but there were no shrubs or any trees. Conformity of the leaves to the sun rays, radiation and wind directions were not negatively affected since they were all exposed at all times courtesy of the slopeness and the absence of canopy. There were $2 \mathrm{~m}$ straight paths in between the plots for easy access by labourers and researcher into each of the plots. Each plot had 2,500 maize stands at $60 \mathrm{~cm} \times 80 \mathrm{~cm}$ spacings.

\section{Measurements of Parameters}

Temperatures were measured using digital thermometer, (model SW-1189), made by Uniscope Nig. Ltd made in Nigeria and relative humidities were measured using hygrometer of model M50.60101, No. 023460, made in France. Measurements were made at $08.00 \mathrm{~h}$ and $14.00 \mathrm{~h}$ for morning and $14.00 \mathrm{hr}$ and $16.00 \mathrm{hr}$ for afternoon each day for the period of 70 days when the maize was on the field. This provides the avenue for calculating the average Temperature-Humidity Index (THI) for every ten days intervals using Marai et al. (2001) equation 2 above.

The nutrient composition of the soil as at the time of planting of maize, the available water present and the extent of their usage, all were analysed for each of the plots to make sure that the soil contain necessary nutrients for the crop growth and for conventional purposes.

Crop productivity $(\mathrm{CP})$, defined as crop yield $(\mathrm{P})$ per cubic metre of water and nutrient consumption including 'green' water (effective rainfall) for rainfed areas and both green and 'blue' water (diverted water from water systems) for irrigated areas was measured in term of maize yield/harvest index (IFARI, 2002). If $\mathrm{P}$ is the crop yield, $\mathrm{kg}$, and $\mathrm{NC}$ is nutrient and water consumption, $\mathrm{m}^{3}$.

$$
\text { Then } \quad \mathrm{CP}=\frac{P}{N C} \ldots . .(3)
$$

(IFARI, 2002; Keller et al., 1996).

Other parameters used in the maize crop productivity were some performance parameters like the rate of leaves' development over each ten-day interval using the number of leaves on the plant; the broadness and the length within the same period of time. Selected areas, chosen with cluster sampling on the maize field were used in each of the replicates. These areas were selected based on the equal distances from one another and at least for twenty stands on a replicate, the average leaf broadness, leaf length and number of leaves were measured for their development over time and to measure maize crop productivity. Harvesting of maize was done in early August, to avert problem of grains' spoilage as a result of heavy rainfall that could start thereafter (Iken and Amusa, 2004).

For quality measurement of the maize leaves, Leaf Area index, LAI was calculated using measured needle leaf area and the ground surface area (clumping index may also be used when global clumping map or global GPP estimation is available (Antonarakis $e t$ $a l ., 2010)$. The ground surface area in 
the needle canopies were taken when the sun was overhead at the tropics, 12.00 noon. The needle canopies' surface areas were quickly estimated in each case and computed for the points needed.

The Harvest Index, HI, was measured using the summation of the immediate useable parts of maize and the later useable parts. Percent HI was calculated as ratio of weight of immediate useable parts to the weight of later useable parts, (Schauvliege, 1995; Breda, 2003; Lamidi, 2009).

\section{Data Analyses}

The statistical analyses used were one-way ANOVA to determine level of significance at 0.05 and Duncan Multiple Range Test (DMRT) for the separation of mean values. Parameters of maize plant measured were compared to established relationship between the growth of maize plant and different orientations of the furrow slices.

\section{Results and Discussion}

Table 1 revealed the values of some environmental parameters of the wind direction (prevailing direction) and wind speed at $1.5 \mathrm{~m}$ height, temperature values (mean maximum and mean minimum), humidity values (minimum observable days and maximum observable days) for three months of June to August the maize was planted. The average wind speeds for the three months were close with standard deviation of \pm 0.1 , however, the wind speeds at height $1.5 \mathrm{~m}$ were not too close with standard deviation of \pm 6.15 , but the temperature means were of closer values in the three months with standard deviation of \pm 0.71 .

Table 2 shows the nutrient composition of the soil samples from each of the 9 plots at both the top soil (0
$-15 \mathrm{~cm})$ and the sub soil $(15-30 \mathrm{~cm})$, the results revealed some closeness in magnitudes and their variations were apparently small. The results show no statistical differences as the mean values are concerned.

Tables 3 and 4 show temperaturehumidity relation, otherwise referred to as THI for different orientations respectively at morning and afternoon periods. THI mean values with their standard deviations are shown in Table 3 for the morning 08.00 and $10.00 \mathrm{hr}$ and Table 4 for the afternoon in 14.00 and $16.00 \mathrm{hr}$, each at ten days interval.

Significant $(\mathrm{p}>0.05, \mathrm{p}=0.192$, 0.077 ) effect of orientations was not observed on the THI values for morning period (08.00 and $10.00 \mathrm{hr})$, however, there was significant effects $(\mathrm{p}<0.05)$ of the different orientations on the THI values in the afternoon periods at $14.00 \mathrm{hr}$ and $16.00 \mathrm{hr}$ with p-values of 0.041 and 0.044 respectively. Significant differences could not be established among values during their first 50 days on the field, but could be inferred to exist in their last 20 days, Table 3, 4.

The lowest mean THI values were found to be $23.52 \pm 0.00$ and $23.60 \pm 0.00$ ${ }^{\circ} \mathrm{C}$ respectively in $90^{\circ}$ and $60^{\circ}$ orientations and $24.20 \pm 0.07{ }^{\circ} \mathrm{C}$ in $30^{\circ}$ orientation in the morning, Table 3 ; while the lowest mean THI values in the afternoon were $27.43 \pm 0.02$, $28.30 \pm 0.01$ and $24.20 \pm 0.02 \quad{ }^{\circ} \mathrm{C}$ respectively in $90^{\circ}, 60^{\circ}$ and $30^{\circ}$ orientations, Table 4 . The THI values for $90^{\circ}$ in the afternoon was nearly room temperature in the tropics, a temperature value that maize grains will be effectively stored than other orientations. This is shown in their total yield values of $2.386,2.173 \mathrm{~kg}$ and 2.264 tonnes/ha, Table 5. The mean values of THI for the three orientations 
were not statistically different from one another from the Duncan multiple range test in the morning and afternoon periods (Tables 3, 4). It was also observed that for the weather condition of the area and the level of tolerance of maize crop to such weather, the mean THI values in the $90^{\circ}$ orientation was high but moderate than for the $60^{\circ}$ and $30^{\circ}$ orientations. The mean values of THI for the $30^{\circ}$, (1.28 tonnes/ha) orientation was less than expected and maize yield was affected as there was low yield with the $30^{\circ}$ orientation but higher for $60^{\circ}$ and $90^{\circ}(1.35,1.40$ tonnes/ha).

For the yield to increase for maize or any other crop, various parameters that make up growth rate must be well established in the crop (Olaoye and Rotimi, 2010), the leaf broadness, leaf length, number of leaf at the particular time and maize stem girth. All these were well developed in the maize crop planted in the $90^{\circ}$ orientation than others, Figures 2-5 and the yield (1.64 ton/ha) and weight of immediate useable parts, 1.40 ton/acre revealed this.

The average values for THI was plotted, Figure 1, also, Figures 2-5 show ten-days intervals' crop development using leaf broadness, leaf lengths, leaf numbers and maize stem girth respectively. Figure 1 shows a lot of fluctuations, because of variations in the environmental conditions, the variations in THI values due to changes in climatic data of temperature and humidity could have been responsible. At the start of fortieth day to the seventieth day, there was little stabilisation in the level of the THI values varying between $23.60{ }^{\circ} \mathrm{C}$ and $26.90{ }^{\circ} \mathrm{C}$. For this wide range in THI values, Table 3 , for such number of days in the experiment could be surmised to mean that the crop tolerance to the environmental conditions could be moderate in such times since maize thrives well over a very wide range of temperature. The maize could be surmised to have grown well because of the favourable weather and the yield was high as the harvest showed in Table 5, 2.386 tonnes/ha yields and with $16.9 \mathrm{~cm}$ (Figure 2) highest point of broadness of maize leaf in Or. $90^{\circ}$ and $\mathrm{HI}$ of 58.68 and 62.12 . Also, LAI values show that $90^{\circ}$ orientation had less LAI (0.625) compare to $60^{\circ}(0.701)$ orientation between the 25 th and 40th days, but more, 0.775 , than that of $60^{\circ}$ orientation of value 0.770 , between the 40th and 70 th days of the maize on the field. This was advantageous to $90^{\circ}$ orientation in that its LAI values were higher when mostly needed to be so (Chen et al, 1997).

The maize leaves' highest point of broadness, Figure 2, was highest in $90^{\circ}$ orientations, $16.9 \mathrm{~cm}^{2}$, comparing this to 16 in Or. $60^{\circ}$, it was $5.63 \%$ increase for Or. $90^{\circ}$ over Or. $60^{\circ}$. The $\mathrm{R}^{2}$ were $0.880,0.748$ and 0.781 respectively for Or. $90^{\circ}$, Or. $60^{\circ}$ and Or. $30^{\circ}$, this shows stronger relationship between maize leaves' broadness and different orientations. The maize leaves' lengths was highest in Or. $90^{\circ}, 36.9 \mathrm{~cm}$, comparing this with Or. $60^{\circ}, 36.0 \mathrm{~cm}$ and Or. $30^{\circ}, 35.9 \mathrm{~cm}$, Figure 3, it was $2.5 \%$ and $2.79 \%$ increase of Or. $90^{\circ}$ over Or. $60^{\circ}$ and Or. $30^{\circ}$ respectively. The results of the regression analysis of the weekly maize leaves lengths at different orientations as a result of the conditions of the weather of the area over the period show that there were stronger relationship between maize leaves' lengths and the number of days; $\mathrm{R}^{2}=0.978$; $0.977 ; 0.981$ respectively for Or. $90^{\circ}$, Or. $60^{\circ}$ and Or. $30^{\circ}$, Figure 
3. In the same way, there was high correlation and strong relationship between number of maize leaves and different orientations; $\mathrm{R}^{2}=0.881$; $0.893 ; 0.890$ respectively for Or. $90^{\circ}$, Or. $60^{\circ}$ and Or. $30^{\circ}$, Figure 4.

The yield of maize varied from 1.18 to 1.44 tonnes/acre for different orientations, Or. $90^{\circ}$ had the highest, Table 5. With Or. $60^{\circ}$ having lesser number of tonnes of non-useable or later useable parts like the chaff, dry leaves that may be left to decay on the field, and later use for organic manure or fed upon by farmer's animals. The maize harvested was of good quality as they were sold in the open market with no any complaints from the buyers. This was deliberately done to know whether the would-be buyers will have any complaints and thereby poorly bargain its price from others in the market. Also, for the THI at different orientations against the maize growth parameters measured in the research (broadness, leaf length and number of leaves per maize stand, stem girth), the $90^{\circ 0}$ has highest correlation and strong relationship than other two orientations $60^{\circ}$ and $30^{\circ}$.

The HI was high for Or. $60^{\circ}$ than Or. $90^{\circ}$, this was as a result of varying values of the replicates in the Or. $60^{\circ}$ that was revealed in the standard deviation, $1.35 \pm 0.09$ compare to 1.40 \pm 0.01 in Or. $90^{\circ}$. Therefore maize planted toward Or. $60^{\circ}$ than Or. $90^{\circ}$ would be able to do well provided land grading was done before planting to prevent water erosion and also to construct peripheral watershed channel around the plot to retain runoff from the plot.

\section{Conclusion}

At oriented furrow slice at $90^{\circ}$ degrees to the prevailing wind direction, the maize will do well in yield for more economic benefit for the farmers. Provided land grading is done, furrow slice for maize can be oriented toward Or. $90^{\circ}$ for more harvest for farmers.

\section{References}

Abubakar, S.S. and Abubakar, S.Z. (1997). Appropriate tillage equipment utilization: the role of extension services. In: Tillage Res. and Agricultural Dev. in Sub-Saharan Africa. Proc. of the Nig. Branch of ISTRO, pp 87-97. Ammani, A.A., Ja'afaru, A.K., Aliytu, J.A. and Arab, A.I. (2012). Climate change and Maize Production: Empirical Evidence from Kaduna State, Nigeria. Journal of Agricultural Extension, 16(1): 1 - 8 .

Antonarakis, A.S., Richards, K.S. Brasington, J. and Muller, E. (2010). Determining leaf area index and leafy tree roughness using terrestrial laser scanning. Journal of Water Resources, 46; W06510, pp12.

Breda, N.J.J. (2003). Ground-based measurements of Leaf Area Index: a review of, instruments and current controversies. Jour. of Experimental Botany, 54(329): 2403-2417

Carns, JiU E., Hellin, J. Sonder, K., Arens, J.L, MacRobert, J.F., Thierfelder, $\mathrm{C}$ and Prasanna, B.M. (2013). Adapting Maize Production to Climate Change in sub-Saharan Africa. Food Sec., 5: $345-360$

Chen, J.M., Rich, P.M., Gower, S.T., Norman, J.M. and Plummer, S. (1997). Leaf Area Index of boreal forests: Theory, techniques and measurement. 
Journal of Geophysics Resources 102: 29429-29443.

Fageria, N.K. (2009). Crop Responses to Environment, http://books.google.com/books

Fageria, N.K., Baligar, V.C. and Ralph, B.C. (2009). Growth and Mineral Nutrition in crops, http://books.google.com/books

Ibrahim, K., Shamsudin, M.N., Yacob, $\mathrm{V}$ and Radam, A. (2014). Economic Impact of Climate Change on Maize Production in Northern Nigeria. Trends in Applied Sciences Research, 9: 522-533.

Iken, J.E. and Amusa, N.A. (2004). Maize research and production in Nigeria. Afri. J. Biotechnol., 3(6): 302-307.

International Food and Agricultural Research Institute (IFARI), (2002). World Water and Food to 2025 Dealing with Scarcity. Washington D. C. Int'l Food and Agricultural Research Institute, pp 98 .

International Food Policy Research Institute (IFPRI), (2004). Assuring Food and Nutrition Security in Africa by 2020. Proceedings of an All- African Conference (Ed: Ketema S.) IFPRI 2020 vision, April 1-3, 2004 Kampala, Uganda (Washington, D.C. IFPRI, 2004), pp 102-104.

Keller A., Keller, V and Seckler, D. (1996). Integrated water resources system theory and policy irrigation. Research report no 3 Colombo, Sri Lanka Int'l Water Management Institute, pp 102.

Lamidi W. A. (2013). Maize (ZeaMays) performance at different cultivation systems. Journal of
Biology, Agriculture and Healthcare, 3(3): 172-182.

Lamidi, W.A. (2009). Introduction to Crop Production. Second edition, Remi Osarayi \& sons Enterprises Ltd, Station Rd, Osogbo, pp 6 and 53-56.

Marai, I.F.M., Ayyat, M.S. and Abd ElMonem, U.M. (2001). Growth Performance and Reproductive Traits at first parity of NZW female Rabbits as affected by Heat Stress and its Alleviation, under Egyptian conditions. Journal of Trop. Ani. Health and Prod., 33: 1-12.

Ogunjimi, O, Ogunjimi, $\mathrm{O}$. and Durojaiye, A. (2014). Technical Efficiency and Constraints among medium scale maize production in Oyo State, Nigeria. Journal of Biology, Agriculture and Health care, 4(24): 91-97.

Olaoye, J.O., Rotimi, A.O. (2010). Measurement of agricultural mechanization index and analysis of agricultural productivity of farm settlements in Southwest Nigeria. Agric. Eng. Int. J., 12(1): 125-134.

Plessis, Jean du (2003). Maize Production. Department of Agriculture, Republic of South Africa

QiJin, H and GuengHeng Z. (2012). The climatic suitability for maize cultivation in China. Chinese Science Bulletin, 57 (4): 395-403

Schauvliege, M. (1995). Caccumulation in old stands of the Aelmoeseneie forest. Master Thesis, Universiteit Gent, Faculteit van de landbouwkundige en Toegepaste Biologische Wetenschappen, pp 99. 
Schwab, G.O., Frevert, R.K. Watson, D. (2015). Maize crop- What Edminister, T.W. and Barnes, K.K. (1981). Soil and Water Conservation Engineering. John Wiley and Sons Inc., New York, Third Edition. next? What ideas and aspiration do you have for maize phase II. CGIAR Research Programme on Maize. Newsletter 4

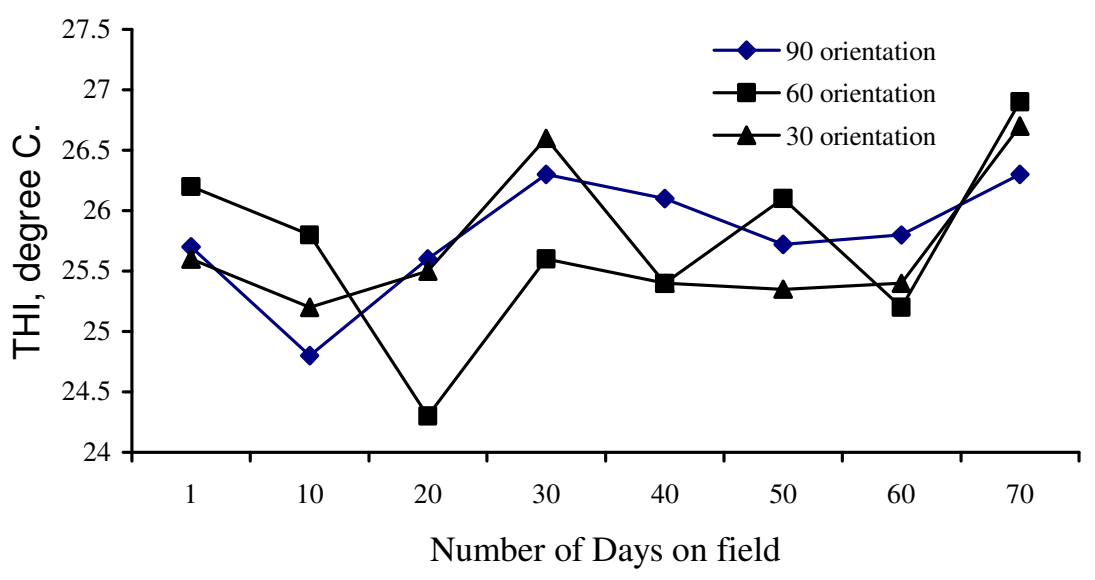

Figure 1: THI values for the three orientations in days

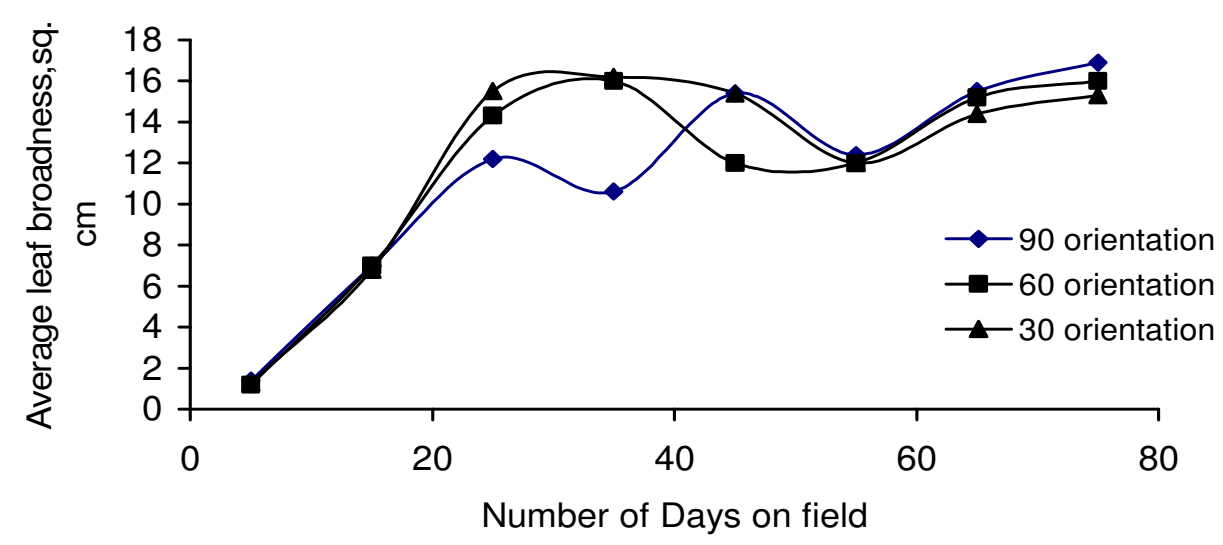

Figure 2: Average leaves' broadness for maize in different fields, $\mathrm{cm}$ 


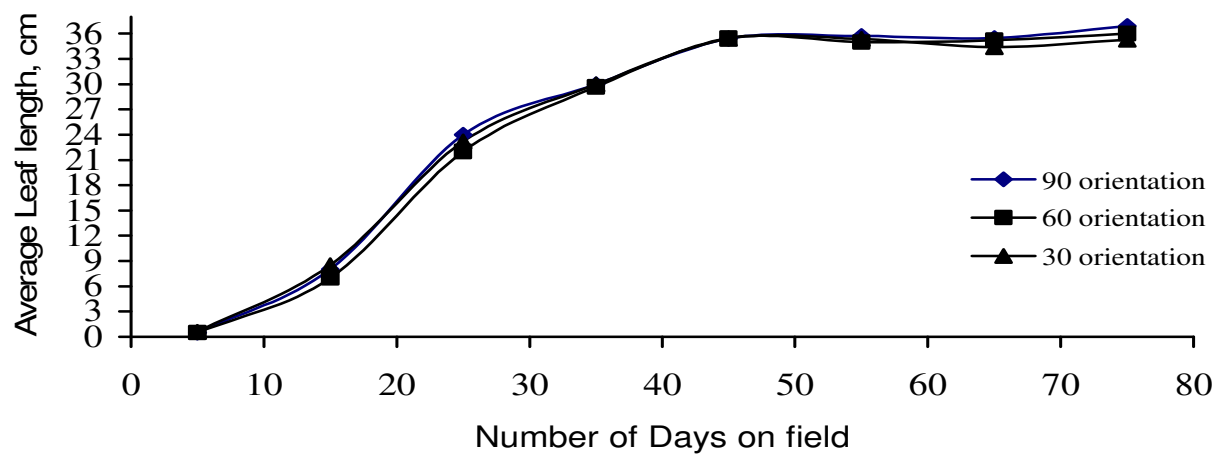

Figure 3: Average leaves' lengths for maize in different fields, $\mathrm{cm}$

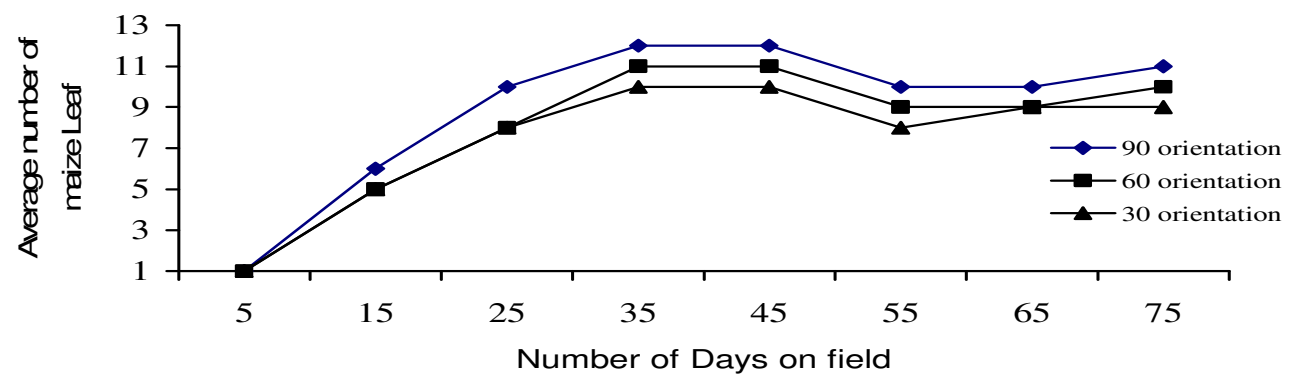

Figure 4: Average numbers of maize Leaf in days

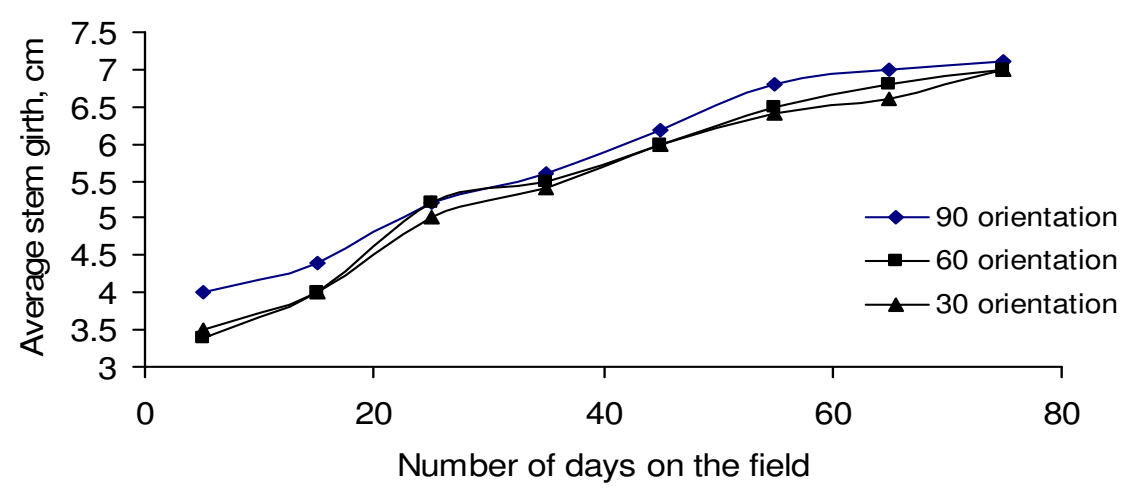

Figure 5: Average length of maize stem girth in days 
Table 1: Average of wind speeds, temperature at certain days measured during the three months planting

\begin{tabular}{|c|c|c|c|c|c|c|c|c|c|}
\hline \multirow[t]{2}{*}{ Months } & \multicolumn{3}{|c|}{ Wind speed, knot } & \multicolumn{4}{|c|}{ Temperature, ${ }^{0} \mathrm{C}$} & \multicolumn{2}{|c|}{ Humidity, mm } \\
\hline & Average & $\begin{array}{l}\text { Height, } \\
1.5 \mathrm{~m}\end{array}$ & $\begin{array}{l}\text { Prevailing } \\
\text { direction }\end{array}$ & $\begin{array}{l}\text { Mean } \\
\text { max. }\end{array}$ & $\begin{array}{l}\text { Mean } \\
\text { min. }\end{array}$ & Mean & $\begin{array}{l}\text { Departure } \\
\text { from } \\
\text { normal }\end{array}$ & $\begin{array}{l}\text { Max. } \\
\text { obs., } \\
\text { day }\end{array}$ & $\begin{array}{l}\text { Min. } \\
\text { obs., } \\
\text { day }\end{array}$ \\
\hline $1^{\text {st }}$ & 4.3 & 40 & SW & 31 & 22.6 & 26.2 & 0.0 & 44.6 & 33 \\
\hline $2^{\text {nd }}$ & 4.1 & 36.5 & SW & 30 & 22.1 & 25.2 & 0.0 & 64.8 & 32.4 \\
\hline $3^{\text {rd }}$ & 4.1 & 31.3 & SW & 30 & 20.9 & - & 0.0 & - & - \\
\hline
\end{tabular}

Mean Max. - Mean Maximum; Mean Min.- Mean Minimum; Max .obs. day- Maximum observed day;

Min. obs. day-Minimum observed day, Source: Meteorological Station at the Farm

Table 2: CEC and Exchangeable cations in the top-soil (0-15cm) and sub-soil (15$30 \mathrm{~cm}$ ) layers

\begin{tabular}{|c|c|c|c|c|c|c|c|c|c|}
\hline \multirow[t]{2}{*}{ Treatments } & \multirow[t]{2}{*}{$\mathrm{DEPTH} / \mathrm{cm}$} & \multicolumn{3}{|c|}{ Nutrients } & \multicolumn{4}{|c|}{ Exchangeable cations } & \multirow{2}{*}{$\begin{array}{l}\text { CEC } \\
\text { Acidity } \\
\text { Cmol/kg }\end{array}$} \\
\hline & & $\begin{array}{l}\text { \% Total } \\
\mathrm{P}\end{array}$ & $\begin{array}{l}\% \\
\text { O.C }\end{array}$ & $\% \mathrm{~N}$ & $\begin{array}{l}\mathrm{Cmol} / \\
\mathrm{kg} \mathrm{Ca}\end{array}$ & $\begin{array}{l}\mathrm{Cmol} / \\
\mathrm{kg} \mathrm{Mg}\end{array}$ & $\begin{array}{l}\mathrm{Cmol} / \\
\mathrm{kg} \mathrm{K}\end{array}$ & $\begin{array}{l}\mathrm{Cmol} / \\
\mathrm{kg} \mathrm{Na}\end{array}$ & \\
\hline \multirow[t]{2}{*}{ A1 } & $0-15$ & 0.24 & 3.542 & 0.347 & 7.458 & 1.267 & 0.411 & 1.328 & 0.45 \\
\hline & $15-30$ & 0.118 & 2.527 & 0.276 & 6.348 & 1.282 & 0.337 & 1.467 & 1.20 \\
\hline \multirow[t]{2}{*}{ A2 } & $0-15$ & 0.278 & 3.785 & 0.393 & 9.074 & 1.209 & 0.545 & 1.682 & 0.60 \\
\hline & $15-30$ & 0.095 & 2.038 & 0.222 & 3.27 & 0.806 & 0.192 & 1.196 & 0.70 \\
\hline \multirow{2}{*}{ A3 } & $0-15$ & 0.263 & 2.615 & 0.375 & 10.896 & 1.327 & 0.451 & 1.504 & 0.71 \\
\hline & $15-30$ & 0.097 & 2.534 & 0.266 & 6.762 & 1.944 & 0.804 & 1.545 & 0.70 \\
\hline \multirow[t]{2}{*}{ B1 } & $0-15$ & 0.281 & 2.035 & 0.291 & 6.516 & 1.333 & 0.462 & 1.388 & 0.70 \\
\hline & $15-30$ & 0.121 & 3.170 & 0.312 & 11.625 & 3.225 & 0.623 & 0.842 & 0.69 \\
\hline \multirow[t]{2}{*}{ B2 } & $0-15$ & 0.288 & 3.562 & 0.298 & 8.426 & 1.367 & 0.429 & 1.318 & 0.60 \\
\hline & $15-30$ & 0.222 & 3.572 & 0.299 & 6.445 & 1.84 & 0.427 & 1.492 & 1.20 \\
\hline \multirow[t]{2}{*}{ B3 } & $0-15$ & 0.286 & 2.885 & 0.333 & 9.171 & 1.129 & 0.705 & 1.284 & 0.60 \\
\hline & $15-30$ & 0.397 & 2.238 & 0.292 & 3.227 & 0.826 & 0.571 & 1.284 & 0.60 \\
\hline \multirow[t]{2}{*}{$\mathrm{C} 1$} & $0-15$ & 0.236 & 2.725 & 0.354 & 9.812 & 1.372 & 0.472 & 1.494 & 0.60 \\
\hline & $15-30$ & 0.117 & 2.444 & 0.226 & 7.262 & 1.823 & 0.779 & 1.555 & 0.50 \\
\hline \multirow[t]{2}{*}{$\mathrm{C} 2$} & $0-15$ & 0.288 & 2.195 & 0.288 & 6.533 & 1.032 & 0.669 & 1.373 & 0.50 \\
\hline & $15-30$ & 0.142 & 3.173 & 0.352 & 10.525 & 2.775 & 0.541 & 0.998 & 0.60 \\
\hline \multirow[t]{2}{*}{$\mathrm{C} 3$} & $0-15$ & 0.238 & 2.865 & 0.272 & 8.406 & 1.656 & 0.494 & 1.224 & 1.15 \\
\hline & $15-30$ & 0.292 & 3.487 & 0.311 & 6.452 & 1.864 & 0.571 & 1.479 & 0.65 \\
\hline
\end{tabular}


Table 3: Mean THI Values* for orientations in the morning

\begin{tabular}{|c|c|c|c|c|c|c|c|c|c|}
\hline \multirow{2}{*}{$\begin{array}{l}\text { Treatment/ } \\
\text { Time }\end{array}$} & \multirow{2}{*}{$\begin{array}{l}\text { Or. } \\
\left(^{0}\right)\end{array}$} & \multicolumn{8}{|c|}{ Days } \\
\hline & & 1 & 10 & 20 & 30 & 40 & 50 & 60 & 70 \\
\hline $\mathrm{A}$ & 90 & $24.80 \pm 0.03^{\mathrm{a}}$ & $23.90 \pm 0.01^{\mathrm{a}}$ & $24.55 \pm 0.00^{\mathrm{a}}$ & $26.60 \pm 0.02^{b}$ & $25.80 \pm 0.02^{\mathrm{a}}$ & $26.85 \pm 0.03^{b}$ & $26.40 \pm 0.02^{b}$ & $26.80 \pm 0.03^{b}$ \\
\hline \multirow[t]{2}{*}{$08.00 \mathrm{hr}$} & 60 & $24.30 \pm 0.04^{\mathrm{a}}$ & $23.52 \pm 0.00^{\mathrm{a}}$ & $24.50 \pm 0.00^{\mathrm{a}}$ & $26.60 \pm 0.00^{\mathrm{b}}$ & $25.40 \pm 0.04^{\mathrm{a}}$ & $25.35 \pm 0.01^{\mathrm{a}}$ & $26.40 \pm 0.03^{b}$ & $26.30 \pm 0.13^{b}$ \\
\hline & 30 & $24.20 \pm 0.07^{\mathrm{a}}$ & $24.80 \pm 0.02^{\mathrm{a}}$ & $24.30 \pm 0.00^{\mathrm{a}}$ & $26.60 \pm 0.01^{\mathrm{b}}$ & $25.40 \pm 0.00^{\mathrm{a}}$ & $26.30 \pm 0.02^{b}$ & $26.20 \pm 0.00^{\mathrm{b}}$ & $26.90 \pm 0.10^{\mathrm{b}}$ \\
\hline B & 90 & $24.60 \pm 0.03^{\mathrm{a}}$ & $24.30 \pm 0.01^{\mathrm{a}}$ & $24.50 \pm 0.00^{\mathrm{a}}$ & $25.20 \pm 0.01^{\mathrm{a}}$ & $24.50 \pm 0.02^{\mathrm{a}}$ & $23.60 \pm 0.00^{\mathrm{a}}$ & $24.30 \pm 0.02^{\mathrm{a}}$ & $25.10 \pm 0.03^{\mathrm{a}}$ \\
\hline \multirow[t]{2}{*}{$08.00 \mathrm{hr}$} & 60 & $24.20 \pm 0.05^{\mathrm{a}}$ & $25.80 \pm 0.01^{\mathrm{a}}$ & $24.30 \pm 0.01^{\mathrm{a}}$ & $25.60 \pm 0.01^{\mathrm{a}}$ & $25.40 \pm 0.02^{\mathrm{a}}$ & $26.10 \pm 0.01^{\mathrm{b}}$ & $25.20 \pm 0.01^{\mathrm{a}}$ & $26.90 \pm 0.00^{b}$ \\
\hline & 30 & $24.60 \pm 0.06^{\mathrm{a}}$ & $24.52 \pm 0.01^{\mathrm{a}}$ & $24.50 \pm 0.00^{\mathrm{a}}$ & $25.60 \pm 0.01^{\mathrm{a}}$ & $24.40 \pm 0.01^{\mathrm{a}}$ & $24.35 \pm 0.00^{\mathrm{a}}$ & $25.40 \pm 0.00^{\mathrm{a}}$ & $24.30 \pm 0.01^{\mathrm{a}}$ \\
\hline $\mathrm{C}$ & 90 & $24.50 \pm 0.01^{\mathrm{a}}$ & $24.50 \pm 0.02^{\mathrm{a}}$ & $24.30 \pm 0.01^{\mathrm{a}}$ & $25.35 \pm 0.02^{\mathrm{a}}$ & $24.39 \pm 0.02^{\mathrm{a}}$ & $24.50 \pm 0.00^{\mathrm{a}}$ & $25.05 \pm 0.00^{\mathrm{a}}$ & $24.60 \pm 0.03^{\mathrm{a}}$ \\
\hline \multirow[t]{2}{*}{$08.00 \mathrm{hr}$} & 60 & $24.30 \pm 0.04^{\mathrm{a}}$ & $24.60 \pm 0.01^{\mathrm{a}}$ & $24.30 \pm 0.01^{\mathrm{a}}$ & $25.55 \pm 0.01^{\mathrm{a}}$ & $24.39 \pm 0.01^{\mathrm{a}}$ & $24.10 \pm 0.01^{\mathrm{a}}$ & $24.20 \pm 0.03^{\mathrm{a}}$ & $23.90 \pm 0.03^{\mathrm{a}}$ \\
\hline & 30 & $24.50 \pm 0.03^{\mathrm{a}}$ & $24.42 \pm 0.02^{\mathrm{a}}$ & $24.50 \pm 0.00^{\mathrm{a}}$ & $25.60 \pm 0.02^{\mathrm{a}}$ & $24.40 \pm 0.01^{\mathrm{a}}$ & $24.35 \pm 0.02^{\mathrm{a}}$ & $24.40 \pm 0.00^{\mathrm{a}}$ & $24.30 \pm 0.10^{\mathrm{a}}$ \\
\hline A & 90 & $26.20 \pm 0.03^{\mathrm{a}}$ & $25.80 \pm 0.01^{\mathrm{a}}$ & $24.30 \pm 0.00^{\mathrm{a}}$ & $25.60 \pm 0.00^{\mathrm{a}}$ & $25.40 \pm 0.01^{\mathrm{a}}$ & $26.10 \pm 0.01^{\mathrm{b}}$ & $25.20 \pm 0.02^{\mathrm{a}}$ & $26.90 \pm 0.03^{b}$ \\
\hline \multirow[t]{2}{*}{$10.00 \mathrm{hr}$} & 60 & $26.30 \pm 0.04^{b}$ & $24.50 \pm 0.00^{\mathrm{a}}$ & $24.50 \pm 0.01^{\mathrm{a}}$ & $25.60 \pm 0.00^{\mathrm{a}}$ & $25.40 \pm 0.03^{\mathrm{a}}$ & $26.15 \pm 0.01^{\mathrm{b}}$ & $25.40 \pm 0.00^{\mathrm{a}}$ & $24.00 \pm 0.10^{\mathrm{a}}$ \\
\hline & 30 & $25.30 \pm 0.04^{\mathrm{a}}$ & $24.52 \pm 0.01^{\mathrm{a}}$ & $25.50 \pm 0.02^{\mathrm{a}}$ & $26.60 \pm 0.01^{\mathrm{b}}$ & $25.40 \pm 0.00^{\mathrm{a}}$ & $25.35 \pm 0.02^{\mathrm{a}}$ & $24.40 \pm 0.00^{\mathrm{a}}$ & $25.30 \pm 0.08^{\mathrm{a}}$ \\
\hline B & 90 & $26.30 \pm 0.03^{\mathrm{a}}$ & $26.50 \pm 0.00^{\mathrm{b}}$ & $24.50 \pm 0.01^{\mathrm{a}}$ & $25.60 \pm 0.02^{\mathrm{a}}$ & $25.40 \pm 0.02^{\mathrm{a}}$ & $26.05 \pm 0.01^{\mathrm{b}}$ & $25.40 \pm 0.00^{\mathrm{a}}$ & $26.30 \pm 0.00^{b}$ \\
\hline \multirow[t]{2}{*}{$10.00 \mathrm{hr}$} & 60 & $26.20 \pm 0.02^{b}$ & $25.80 \pm 0.01^{\mathrm{a}}$ & $24.30 \pm 0.01^{\mathrm{a}}$ & $25.60 \pm 0.01^{\mathrm{b}}$ & $25.40 \pm 0.04^{\mathrm{a}}$ & $26.10 \pm 0.01^{b}$ & $25.20 \pm 0.00^{\mathrm{a}}$ & $26.50 \pm 0.01^{b}$ \\
\hline & 30 & $26.40 \pm 0.01^{\mathrm{b}}$ & $25.50 \pm 0.03^{\mathrm{a}}$ & $24.50 \pm 0.01^{\mathrm{a}}$ & $25.50 \pm 0.01^{\mathrm{a}}$ & $25.40 \pm 0.01^{\mathrm{a}}$ & $26.35 \pm 0.03^{b}$ & $25.40 \pm 0.00^{\mathrm{a}}$ & $26.40 \pm 0.00^{b}$ \\
\hline $\mathrm{C}$ & 90 & $27.40 \pm 0.02^{\mathrm{b}}$ & $27.40 \pm 0.02^{\mathrm{b}}$ & $26.45 \pm 0.01^{\mathrm{b}}$ & $26.40 \pm 0.01^{\mathrm{b}}$ & $25.85 \pm 0.01^{\mathrm{a}}$ & $26.40 \pm 0.01^{\mathrm{b}}$ & $25.20 \pm 0.02^{\mathrm{a}}$ & $26.70 \pm 0.03^{b}$ \\
\hline \multirow[t]{2}{*}{$10.00 \mathrm{hr}$} & 60 & $27.20 \pm 0.02^{b}$ & $26.80 \pm 0.01^{\mathrm{b}}$ & $26.30 \pm 0.01^{\mathrm{b}}$ & $26.60 \pm 0.00^{\mathrm{b}}$ & $25.40 \pm 0.01^{\mathrm{a}}$ & $26.10 \pm 0.01^{\mathrm{b}}$ & $25.20 \pm 0.00^{\mathrm{a}}$ & $26.90 \pm 0.00^{b}$ \\
\hline & 30 & $25.30 \pm 0.03^{\mathrm{a}}$ & $26.50 \pm 0.02^{\mathrm{b}}$ & $26.50 \pm 0.02^{\mathrm{b}}$ & $26.50 \pm 0.01^{\mathrm{b}}$ & $25.40 \pm 0.00^{\mathrm{a}}$ & $26.35 \pm 0.01^{\mathrm{b}}$ & $25.40 \pm 0.00^{\mathrm{a}}$ & $26.30 \pm 0.10^{b}$ \\
\hline
\end{tabular}

*Mean values with the same letter along the same row are not significantly different, $\mathrm{p} \leq 0.05$ 
Table 4: Mean THI Values* for different orientations in the afternoon

\begin{tabular}{|c|c|c|c|c|c|c|c|c|c|}
\hline \multirow{2}{*}{$\begin{array}{l}\text { Treatment/ } \\
\text { Time }\end{array}$} & \multirow{2}{*}{$\begin{array}{l}\text { Or. } \\
\left({ }^{0}\right)\end{array}$} & \multicolumn{8}{|c|}{ Days } \\
\hline & & 1 & 10 & 20 & 30 & 40 & 50 & 60 & 70 \\
\hline A & 90 & $29.44 \pm 0.01^{\mathrm{a}}$ & $31.80 \pm 0.01^{\mathrm{a}}$ & $32.15 \pm 0.00^{\mathrm{a}}$ & $33.15 \pm 0.01^{\mathrm{a}}$ & $32.72 \pm 0.02^{\mathrm{a}}$ & $27.43 \pm 0.02^{b}$ & $31.48 \pm 0.00^{b}$ & $31.70 \pm 0.01^{b}$ \\
\hline \multirow[t]{2}{*}{$14.00 \mathrm{hr}$} & 60 & $28.30 \pm 0.01^{\mathrm{a}}$ & $30.50 \pm 0.00^{\mathrm{a}}$ & $30.50 \pm 0.00^{\mathrm{a}}$ & $31.60 \pm 0.00^{\mathrm{b}}$ & $31.40 \pm 0.00^{\mathrm{b}}$ & $28.35 \pm 0.01^{\mathrm{a}}$ & $29.40 \pm 0.00^{\mathrm{a}}$ & $31.30 \pm 0.01^{\mathrm{b}}$ \\
\hline & 30 & $29.00 \pm 0.02^{a}$ & $30.20 \pm 0.00^{\mathrm{a}}$ & $31.50 \pm 0.00^{\mathrm{b}}$ & $31.30 \pm 0.00^{\mathrm{b}}$ & $31.40 \pm 0.00^{\mathrm{b}}$ & $28.35 \pm 0.01^{\mathrm{a}}$ & $30.40 \pm 0.01^{\mathrm{a}}$ & $30.20 \pm 0.03^{\mathrm{a}}$ \\
\hline B & 90 & $30.23 \pm 0.01^{\mathrm{a}}$ & $29.83 \pm 0.01^{\mathrm{a}}$ & $30.40 \pm 0.00^{\mathrm{a}}$ & $30.40 \pm 0.00^{\mathrm{a}}$ & $30.45 \pm 0.01^{\mathrm{a}}$ & $30.23 \pm 0.01^{\mathrm{a}}$ & $30.30 \pm 0.02^{\mathrm{a}}$ & $30.60 \pm 0.02^{\mathrm{a}}$ \\
\hline \multirow[t]{2}{*}{$14.00 \mathrm{hr}$} & 60 & $29.30 \pm 0.00^{\mathrm{a}}$ & $29.52 \pm 0.01^{\mathrm{a}}$ & $29.50 \pm 0.02^{\mathrm{a}}$ & $30.60 \pm 0.00^{\mathrm{a}}$ & $29.40 \pm 0.01^{\mathrm{a}}$ & $29.35 \pm 0.01^{\mathrm{a}}$ & $30.40 \pm 0.02^{\mathrm{a}}$ & $29.30 \pm 0.10^{\mathrm{a}}$ \\
\hline & 30 & $30.00 \pm 0.00^{\mathrm{a}}$ & $29.50 \pm 0.00^{\mathrm{a}}$ & $30.10 \pm 0.01^{\mathrm{a}}$ & $31.00 \pm 0.01^{\mathrm{b}}$ & $29.70 \pm 0.00^{\mathrm{a}}$ & $29.35 \pm 0.01^{\mathrm{a}}$ & $31.40 \pm 0.02^{\mathrm{b}}$ & $29.30 \pm 0.00^{\mathrm{a}}$ \\
\hline $\mathrm{C}$ & 90 & $30.15 \pm 0.00^{\mathrm{a}}$ & $30.53 \pm 0.01^{\mathrm{a}}$ & $30.30 \pm 0.01^{\mathrm{a}}$ & $30.25 \pm 0.01^{\mathrm{a}}$ & $30.39 \pm 0.02^{\mathrm{a}}$ & $30.15 \pm 0.00^{\mathrm{a}}$ & $30.22 \pm 0.02^{\mathrm{a}}$ & $29.63 \pm 0.03^{\mathrm{a}}$ \\
\hline \multirow[t]{2}{*}{$14.00 \mathrm{hr}$} & 60 & $30.30 \pm 0.01^{\mathrm{a}}$ & $30.10 \pm 0.00^{\mathrm{a}}$ & $30.50 \pm 0.00^{\mathrm{a}}$ & $31.60 \pm 0.01^{\mathrm{b}}$ & $31.40 \pm 0.02^{\mathrm{b}}$ & $31.35 \pm 0.01^{\mathrm{b}}$ & $31.40 \pm 0.01^{\mathrm{b}}$ & $30.30 \pm 0.13^{\mathrm{a}}$ \\
\hline & 30 & $30.00 \pm 0.02^{\mathrm{a}}$ & $30.52 \pm 0.00^{\mathrm{a}}$ & $30.00 \pm 0.00^{\mathrm{a}}$ & $29.60 \pm 0.01^{\mathrm{a}}$ & $30.40 \pm 0.00^{\mathrm{a}}$ & $30.25 \pm 0.00^{\mathrm{a}}$ & $30.20 \pm 0.01^{\mathrm{a}}$ & $29.30 \pm 0.07^{\mathrm{a}}$ \\
\hline A & 90 & $31.25 \pm 0.02^{\mathrm{b}}$ & $31.36 \pm 0.00^{\mathrm{b}}$ & $31.23 \pm 0.03^{\mathrm{b}}$ & $31.40 \pm 0.01^{\mathrm{b}}$ & $31.28 \pm 0.01^{\mathrm{b}}$ & $31.25 \pm 0.00^{\mathrm{b}}$ & $31.48 \pm 0.02^{b}$ & $31.50 \pm 0.03^{\mathrm{b}}$ \\
\hline \multirow[t]{2}{*}{$16.00 \mathrm{hr}$} & 60 & $30.40 \pm 0.02^{\mathrm{a}}$ & $30.50 \pm 0.00^{\mathrm{a}}$ & $30.50 \pm 0.03^{\mathrm{a}}$ & $31.60 \pm 0.00^{\mathrm{b}}$ & $31.00 \pm 0.03^{b}$ & $31.05 \pm 0.01^{\mathrm{b}}$ & $31.00 \pm 0.01^{\mathrm{b}}$ & $30.00 \pm 0.03^{\mathrm{a}}$ \\
\hline & 30 & $30.30 \pm 0.01^{\mathrm{a}}$ & $30.10 \pm 0.00^{\mathrm{a}}$ & $30.50 \pm 0.01^{\mathrm{a}}$ & $31.60 \pm 0.01^{\mathrm{b}}$ & $31.40 \pm 0.00^{\mathrm{b}}$ & $31.00 \pm 0.00^{\mathrm{b}}$ & $31.00 \pm 0.01^{\mathrm{b}}$ & $30.00 \pm 0.00^{\mathrm{a}}$ \\
\hline B & 90 & $32.67 \pm 0.00^{b}$ & $33.40 \pm 0.03^{b}$ & $32.65 \pm 0.01^{\mathrm{b}}$ & $32.47 \pm 0.00^{\mathrm{b}}$ & $32.52 \pm 0.02^{\mathrm{b}}$ & $32.67 \pm 0.01^{b}$ & $32.87 \pm 0.01^{\mathrm{b}}$ & $32.91 \pm 0.03^{b}$ \\
\hline \multirow[t]{2}{*}{$16.00 \mathrm{hr}$} & 60 & $32.30 \pm 0.00^{\mathrm{b}}$ & $33.40 \pm 0.03^{\mathrm{b}}$ & $32.50 \pm 0.01^{\mathrm{b}}$ & $32.60 \pm 0.00^{\mathrm{b}}$ & $32.40 \pm 0.03^{\mathrm{b}}$ & $32.35 \pm 0.01^{\mathrm{b}}$ & $32.40 \pm 0.01^{\mathrm{b}}$ & $32.30 \pm 0.09^{\mathrm{b}}$ \\
\hline & 30 & $32.30 \pm 0.06^{\mathrm{b}}$ & $32.52 \pm 0.02^{b}$ & $32.50 \pm 0.02^{\mathrm{b}}$ & $32.60 \pm 0.00^{\mathrm{b}}$ & $32.40 \pm 0.01^{\mathrm{b}}$ & $31.35 \pm 0.02^{\mathrm{b}}$ & $32.40 \pm 0.00^{\mathrm{b}}$ & $32.20 \pm 0.10^{\mathrm{b}}$ \\
\hline $\mathrm{C}$ & 90 & $31.80 \pm 0.00^{b}$ & $31.63 \pm 0.01^{\mathrm{b}}$ & $31.87 \pm 0.02^{\mathrm{b}}$ & $31.58 \pm 0.02^{b}$ & $31.92 \pm 0.02^{b}$ & $31.58 \pm 0.02^{b}$ & $31.52 \pm 0.01^{b}$ & $31.44 \pm 0.02^{b}$ \\
\hline \multirow{2}{*}{$16.00 \mathrm{hr}$} & 60 & $31.20 \pm 0.02^{b}$ & $31.52 \pm 0.04^{b}$ & $32.80 \pm 0.02^{\mathrm{b}}$ & $31.60 \pm 0.00^{\mathrm{b}}$ & $30.40 \pm 0.01^{\mathrm{a}}$ & $32.35 \pm 0.02^{\mathrm{b}}$ & $32.40 \pm 0.02^{b}$ & $31.30 \pm 0.10^{\mathrm{b}}$ \\
\hline & 30 & $31.30 \pm 0.02^{\mathrm{b}}$ & $31.52 \pm 0.02^{\mathrm{b}}$ & $32.50 \pm 0.01^{\mathrm{b}}$ & $30.60 \pm 0.01^{\mathrm{a}}$ & $31.40 \pm 0.00^{\mathrm{b}}$ & $31.35 \pm 0.02^{\mathrm{b}}$ & $31.40 \pm 0.02^{\mathrm{b}}$ & $32.30 \pm 0.10^{\mathrm{b}}$ \\
\hline
\end{tabular}

*Mean values with the same letter along the same row are not significantly different, $\mathrm{p} \leq 0.05$ 
Table 5: Mean values showing maize crop performance parameters

\begin{tabular}{|llll|}
\hline Maize Crop Performance Parameters & Orientations & & \\
\hline & $90^{0}$ & $60^{0}$ & $30^{0}$ \\
\hline Yield, tonnes /acre & $1.64 \pm 0.20$ & $1.42 \pm 0.48$ & $1.30 \pm 0.20$ \\
\hline Maximum Leaf broadness, $\mathbf{~ m}^{\mathbf{2}}$ & $0.0192 \pm 0.100$ & $0.0183 \pm 0.014$ & $0.0190 \pm 0.01$ \\
\hline Highest leaf length recorded, $\mathbf{~ m}$ & $0.37 \pm 0.04$ & $0.36 \pm 0.02$ & $0.35 \pm 0.03$ \\
\hline Av. number of leaves/maize stand & $9.00 \pm 0.10$ & $8.00 \pm 0.09$ & $7.50 \pm 0.10$ \\
\hline $\begin{array}{l}\text { Weight of immediate useable parts, } \\
\text { tonnes /acre (i) }\end{array}$ & $1.40 \pm 0.01$ & $1.35 \pm 0.09$ & $1.28 \pm 0.10$ \\
\hline $\begin{array}{l}\text { Weight of later useable (or non- } \\
\text { useable) parts tonnes/acre (ii) }\end{array}$ & $0.986 \pm 0.002$ & $0.823 \pm 0.011$ & $0.984 \pm 0.010$ \\
\hline $\begin{array}{l}\text { Total (i + ii) weight produced, } \\
\text { tonnes /acre }\end{array}$ & $2.386 \pm 0.020$ & $2.173 \pm 0.016$ & $2.264 \pm 0.009$ \\
\hline \% HI & 58.68 & 62.12 & 56.54 \\
\hline
\end{tabular}

